Giacomo Pirlo*, Luciano Migliorati, Fabio Abeni, Luigi Degano, Antonio Bruni, Giovanni Cabassi, Milena Povolo

\title{
Effect of supplementing sunflower cake in dairy cow diet on milk production and composition
}

\author{
Effetto dell'aggiunta del panello di girasole alla razione della bovina da latte sulla produzione e \\ composizione del latte
}

CREA - Centro di Ricerca Zootecnia e Acquacoltura, Via Antonio Lombardo 11, 26900, Lodi, Italy

*Corresponding author:

Giacomo Pirlo

CREA-ZA, Via Lombardo 11, 26900 Lodi. Via Lombardo 11, 26900 Lodi. Tel. 037145011 E-mail giacomo.pirlo@crea.gov.it
Ricevuto il 9 dicembre 2019

Accettato il 21 dicembre 2019

DOI: $10.36138 / S T L C .01 .2020 .04$

\section{Abstract}

Objective. Sunflower cake (SFC) is one of the co-products of biodiesel production chain, which can be supplemented in the diet of lactating cows, substituting a portion of soybean meal (SBM). The aim of this experiment was to evaluate the possibility of substituting a portion of SBM with SFC in the diet of lactating cows, by estimating the effects on production and on some milk chemical and physical characteristics.

Materials and methods. The experiment was carried out in two experimental farms in which two groups of sixteen Italian Holstein cows were allotted into two groups, fed SBM and SFC, respectively.

Composition and chemical characteristics of the diets, daily production, gross composition and fat globule size distribution of milk, fatty acid composition of both milk and sunflower cake were determined. Results. SFC supplementation did not affect milk production, but it reduced milk protein percentage; milk fat concentration was only decreased in mid lactation; if the whole lactation is considered, milk fat percentage was not influenced by SFC substitution for partial SBM. Total unsaturated fatty acids significantly increased through SFC supplementation. Both vaccenic and conjugated linoleic acid were higher in milk of cows fed SFC.

Conclusions. Introduction of SFC in dairy cow diet is a feasible strategy to make biodiesel production more profitable. It also seems able to improve the milk nutritional properties.

\section{Keywords: \\ sunflower cake \\ bovine milk \\ - production \\ milk composition}

fatty acids

\section{Riassunto}

Obiettivo. II panello di girasole (SFC) è uno dei coprodotti della catena di produzione del biodiesel, che può essere integrato nella dieta delle bovine, in parziale sostituzione della farina di soia (SBM). In questa ricerca è stata verificata la possibilità di sostituire una quota di SBM con SFC nella dieta delle bovine, stimando gli effetti sulla produzione e su alcune caratteristiche del latte.

Materiali e metodi. l'esperimento è stato condotto in due aziende sperimentali in cui due gruppi di 16 bovine di razza Frisona Italiana sono state divise in due gruppi, alimentati rispettivamente con SBM e SFC. Sono stati determinati: composizione e caratteristiche chimiche delle diete, produzione giornaliera $\mathrm{e}$ macro-composizione del latte, distribuzione delle dimensioni dei globuli di grasso, composizione in acidi grassi del latte e del panello di girasole.

Risultati. L'integrazione con SFC non ha influito sulla produzione di latte, ma ha ridotto la sua percentuale di protei- ne; il contenuto in grasso ha subito una riduzione solo a metà del periodo di lattazione; se si considera l'intera lattazione, la percentuale di grasso del latte non è stata influenzata dalla parziale sostituzione di SBM con SFC. Gli acidi grassi insaturi hanno mostrato un significativo aumento a seguito dell'integrazione con SFC. Sia l'acido linoleico coniugato che il vaccenico sono risultati più elevati nel latte di bovine alimentate con SFC.

Conclusioni. L'introduzione dell'SFC nella dieta delle bovine da latte è una strategia percorribile per rendere la produzione di biodiesel più redditizia. Inoltre, sembra influenzare positivamente le proprietà nutrizionali del latte.
Parole chiave:
- Panello di girasole
- Latte vaccino
- Produzione
- Composizione del latte
- Acidi grassi 


\section{INTRODUCTION}

Utilization of biodiesel is considered one of the strategies for reducing fossil fuel consumption and decreasing the concentration of greenhouse gases in the atmosphere (1). This fuel can be obtained from different vegetable and animal fats and from yellow grease as well (2). The main sources of vegetable oils in the world are soybean and canola; however, sunflower seed are considered suitable in Mediterranean agro-climatic condition (3). According to FAO, in 2017 about 48 Mt of sunflower seeds were produced in the world; Italian production was estimated to be about $213 \mathrm{Kt}$ in the same year (4). About $60 \%$ of the sunflower oil is destinated for the food chain and the remaining $40 \%$ is used in non-food chain, i.e. of bieodiesel production and cosmetics (4). According to ISTAT (5) sunflower for biodiesel oil is cropped on 3000 ha in Italy. In addition to oil, several co-products are obtained from sunflower oil industry; solvent extracted meal is the most common because of its characteristics that make it easier to transport and stock and it is widely used in livestock and poultry industries. An alternative to solvent extracted sunflower meal is cake, that is obtained through the mechanical squeezing of oil seeds, and has a lipid content several times higher than solvent extract meal (7). This characteristic might limit its utilization in lactating dairy cow feeding because, in some experiments it appeared that fat supplements from oilseed crops could affect negatively dry matter intake (DMI), milk production, and milk composition (8).

The use of sunflower oil or seeds are interesting in animal nutrition, because they are potential energy and protein sources, but they could be limited in ruminant diet, because of the high content of linoleic acid (LA) if compared with other vegetable oils (9).

Sarazin et al. (10) found a decrease of DMI of lactating dairy cows as consequence of sunflower seed supplementation; however, other authors (11-15) did not find any effect on DMI. Results about milk production were more inconsistent: in some cases, milk production was decreased by whole sunflower supplementation in lactating dairy cattle diet (11-13); in other cases, it was increased $(14,15)$, and in some others, there was no effect $(10,11)$. Variable results were also observed about milk protein percentage, which was decreased according to Petit et al. (13) and Stegeman et al. (15); instead, it was not affected by supplementation with sunflower seeds according with other authors $(9,11,12,14)$. When fed to lactating dairy cows, sunflower seeds were associated with a reduction of milk fat percentage in the experiments of Sarrazin et al. (10) and Casper et al. (11), but no effect was observed in other trials (12-15).

Effects of sunflower oil as fat supplement in lactating dairy cow diet were studied by Cruz-Hernandez et al. (16), who found no effect on DMI, milk production and fat and protein concentrations. On the contrary, Rego et al. (17) showed that energy corrected milk production and milk fat concentration were negatively affected by sunflower oil. Supplementation of sunflower seeds or oil of dairy cow diet invariably determines a modification of milk fatty acid (FA) profile; with a reduction percentage of saturated fatty acids (SFA) and an increase of mono- and polyunsaturated fatty acids (MUFA and PUFA respectively) (10-12,15-17)

A very promising consequence of supplementation of dairy cow diet with vegetable oils is the possibility to increase the content of cis-9,trans-11 C18:2 (CLA), the main conjugated linoleic acid. Some animal studies suggested that CLA has some health benefits, including anticarcinogenic and antiatherogenic effects and improvements in blood lipid concentrations, although most of these are not unequivocally supported by consistent data from human studies (18). Sarrazin et al. (10) and Cruz-Hernadez et al. (17) obtained a significant increase in CLA concentration in milk fat as dairy cow diets were supplemented with sunflower seeds or oil respectively. Supplementation of diet of lactating cows with sunflower seeds or oil is considered one of the most effective strategies for increasing milk CLA content, because it is well known that primary source of CLA is LA through rumen isomerization and biohydrogenation and through desaturation of vaccenic acid (VA) in mammary gland (19). There is little information about cakes deriving from a simple mechanic extraction of vegetable oils. Compared with solvent-extract oilseed meal, cakes have a higher and more variable lipid content (20), with possible effects on ruminant performances and on quality of animal products. So far, we do not know any experiment aiming at utilizing sunflower cake (SFC) as supplement in dairy cow diet. Objective of this experiment was to evaluate the possibility of substituting a portion of soybean meal (SBM) with SFC in the diet of lactating dairy cows, by estimating the effects on production and on some milk chemical and physical characteristics.

\section{MATERIAL AND METHODS}

\section{Experiment organization}

Two groups of sixteen Italian Holstein cows were kept in two experimental farms for evaluating the effect of partial substitution of SBM with SFC, obtained from mechanical squeezing. All cows were of second or third lactation and of mid (between 80 and 160 days from calving) or late (between 160 and 240 days from calving) stage of lactation. In both farms, cows were allotted into two groups, according to age and stage of lactation; cows of half a group were fed SBM and the others were fed SFC. The diets, administrated as total mixed ration, were isonitrogenous. The rations were distributed on a group-basis to obtain less than $5 \%$ refusals. 
The experimental design was a change-over, replicated in each farm, with periods of three weeks: the first two for adaptation and the third week for data and sample collection.

\section{Diets and chemical characteristics}

The cake was obtained from a regular type of sunflower; chemical composition of SFC are reported in Table I. Cakes were obtained in a Italian oil industry. Chemical composition of both sunflower cake and diets were determined by applying the AOAC methods (21); the nitrogen free-extract was determined by subtracting the percentage of moisture, crude protein, oil, ash, and crude fibre from 100. The lipid matrix was extracted with diethyl ether under reflux, for 6 hours. Transmethylation and gas chromatographic analysis were carried out applying the procedures described in Contarini et al. (22). Cake FA composition is shown on Table II. In the two farms diets were identical, i.e. the same diet and the same concentrates were used. Composition of SBM and SFC diet are reported in Table III and their chemical characteristics are shown in Table IV.

Milk production and composition, FA analysis and fat globule size

Milk production was recorded every two day, two times a day, though lactometers in both farms. Milk composition was estimated through MIR spectrophotometry. The milk fat was extracted by applying the ISO standard 14156 (23). Methyl esters of FAs were obtained according to ISO 15884 (24) and analyzed by using a 100 m GC column, according to Contarini et al. (22). Size of fat globules was evaluated according to Cabassi et al. (25), by adopting ISO 13320 (26) and using a Mastersizer 2000 (Malvern Instruments Ltd, Malvern, Worcestershire, UK) granulometer equipped with a 633 $\mathrm{nm}$ laser source. Fatty globule size was expressed as surface weighted mean, according to Sautern mean - $D(3,2)$; where

$$
D(3,2) \mu m=\frac{\sum_{i} \quad d_{i}^{3} N_{i}}{\sum_{i} \quad d_{i}^{2} N_{i}}
$$

\section{Statistical analysis}

Distribution normality was ascertained by estimating skewness and kurtosis; homogeneity of variance was assessed through $F$ test. Data have been analyzed through GLM procedure of SAS (Release 9.2; SAS Institute Inc., Cary NC), using the following model: trait = farm period(farm) cow(farm) stage treatment stage $x$ treatment. Differences were considered significant for $P<0.05$ and highly significant for $P<0.001$. The effects of farm and period are neither presented or discussed and the effect of stage of lactation is considered when there is a significant interaction with treatment.

\section{Table I. Chemical composition of sunflower cake}

Tabella I Composizione chimica del panello di girasole

\begin{tabular}{lcc}
\hline Dry matter (DM) & (\% weight) & 95.2 \\
\hline Ether extract & (\% DM) & 13.4 \\
\hline Fiber & " & 31.7 \\
\hline Crude protein & " & 25.3 \\
\hline Nitrogen-free extract & " & 23.2 \\
\hline Ash & " & 5.9 \\
\hline
\end{tabular}

\section{Table II. Fatty acid composition of sunflower cake}

Tabella Il. Composizione in acidi grassi del panello di girasole

\begin{tabular}{lc}
\multicolumn{1}{c}{ Fatty acid } & $\%$ on total FAs \\
\hline C14 & 0.12 \\
\hline C16 & 6.57 \\
\hline C17 iso & 0.02 \\
\hline C17 anteiso & 0.12 \\
\hline C17 & 0.03 \\
\hline C18 & 3.32 \\
\hline C18:1 & 32.30 \\
\hline C18:2 & 56.48 \\
\hline C20 & 0.20 \\
\hline C18:3 & 0.20 \\
\hline C23 & 0.01 \\
\hline C24 & 0.15 \\
\hline
\end{tabular}

\section{RESULTS}

Statistical analysis showed that there were no significant interactions between feeding treatment and stage of lactation, except for milk fat concentration, UFAs C10:1 to C14:1, C18, and sum C20 to C22, expressed in percentage on total milk FAs (Tab. V and VI). Partial substitution of SBM with SFC (Tab. III) did not influence milk production and milk fat content; on the contrary, it determined a significant $(P<0.005)$ reduction of milk protein content (Table V). Feeding effect on milk fat concentration was influenced by stage of lactation (Fig. 1). 
Table III. Composition of control (SBM) and experimental (SFC) diets (kg/d per cow as fed)

Tabella III. Composizione (kg t.q./d/capo) della dieta controllo (SBM) e sperimentale (SFC)

Diet

\begin{tabular}{|c|c|c|}
\hline Feed & SBM & SFC \\
\hline Maize silage & 24 & 26 \\
\hline Alfalfa hay & 2 & 2 \\
\hline Grass hay & 2 & 2 \\
\hline Whole cottonseeds & 1 & 1 \\
\hline Grain and protein mix & 3,6 & 3,6 \\
\hline Soybean meal & 2 & - \\
\hline Sunflower cake & - & 2 \\
\hline Ground maize & 4,8 & 4,8 \\
\hline Vitamin and mineral supplement & 0,2 & 0,2 \\
\hline Sodium bicarbonate & 0,1 & 0,1 \\
\hline Total soyben meal & 2,5 & 0,5 \\
\hline Total sunflower cake & - & 2 \\
\hline
\end{tabular}

\section{Table IV. Chemical characteristics of control (SBM) and experimental (SFC) diets}

Tabella IV Caratteristiche chimiche della dieta controllo (SBM) e sperimentale (SFC).

\begin{tabular}{lccc} 
& & \multicolumn{3}{c}{ Diet } \\
\cline { 3 - 4 } & & SBM & SFC \\
\cline { 2 - 4 } DM & (\% weight) & 55.1 & 57.4 \\
\hline Crude protein & (\% of DM) & 15.5 & 15.4 \\
\hline Neutral detergent fiber & " & 36.7 & 39.4 \\
\hline Acid detergent fiber & " & 20.6 & 23.8 \\
\hline Ether extract & " & 3.7 & 4.4 \\
\hline Starch & " & 25.5 & 24.6 \\
\hline Ash & " & 5,7 & 5.8 \\
\hline
\end{tabular}

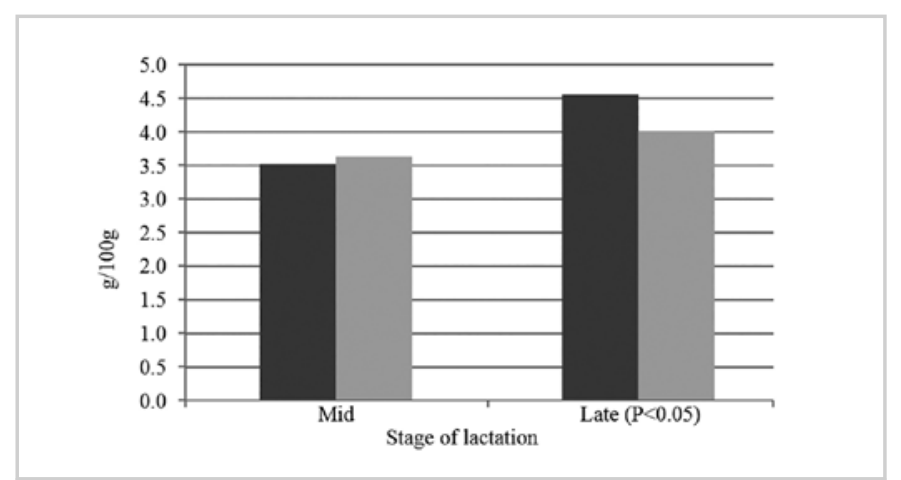

Figure 1. Milk fat percentage of cows fed SBM (black bars) or SFC (gray bars) diet in mid or late stage of lactation.

Figura 1. Percentuale di grasso del latte di bovine alimentate con SBM (barre in nero) o SFC (barre in grigio) nel medio e avanzato stadio di lattazione.

Composition of milk FAs has been reported on Table VI. Supplementation of SFC modified the proportion of several FAs, decreasing $(P<0.001)$ percentage of palmitic acid $(C 16)$ and of total SFAs. Sunflower cake increased $(P<0.001)$ UFAs $C 10: 1$ to $C 14: 1$, C16:1cis7 + C16:1cis 9, stearic acid (C18), oleic acid (C18:1), VA, CLA, sum C20 to C22, total UFA, MUFA, and PUFA. Supplementation of SFC did not influence concentration of C4 to C14, C17:1, arachidonic acid (C20:4n6), and n-3 fatty acids ( $\omega-3)$. Analysis of variance pointed out a significant $(P<0.05)$ effect of the interaction between feeding treatment and stage of lactation for the UFAs C10:1 to C14:1 (Fig. 2), C18 (Fig. 3), and sum C20 to C22 (Fig. 4). Partial substitution of SMB with SFC (Tab. III) did not modify size $\left(d_{32}\right)$ of milk fat globules (3.24 $\mu$ in SBM versus $3.22 \mu$ in SFC).

\section{DISCUSSION}

Cows fed SFC had the same daily milk production of cows on SBM diet, in both mid and late lactation (Tab. V). Dry matter intake is considered to be one of the main drivers of milk production. The effect of administration of sunflower seeds to lactating cows on DMI is controversial, because some authors $(10,11)$ observed a reduction of DMI and others (11-15) that did not. In the present experiment, we did not measured individual DMI so that we do not know if there was a difference in this parameter between the two groups of animals; however we cannot exclude that the substitution of SFC for a portion of SBM could have lowered DMI, because in the literature, increases of milk production, as consequence of administration of diets containing sunflower seeds, were normally associated with a neutral effect on DMI $(11,15,14)$. 
The experimental design does not allow to solve the problem whether a possible reduction of DMI associated with a stable milk production can determine an excessive mobilization of body reserves. However, in his review, Chilliard (27) reported that dietary fats do not influence body weight gain after peak of lactation, but can increase body weight losses in the early stage and we have no reason to exclude that substitution of SFC for a portion of SBM can affect body reserve recovery during mid and late lactation.

Substitution of a portion SBM with SFC significantly decreased milk protein concentration in both mid and late lactation (Tab. V). A similar result was observed in the experiments of Petit et al. (13) and Stegeman et al. (15) with sunflower seeds; whereas no effects on milk protein content were recorded by Sarrazin et al. (10), Casper et al. (11), McGuffy and Schingoethe (12), Rafalowski and Park (14) with sunflower seeds and by Cruz-Hernandez et al. (16) and Rego et al. (17) with sunflower oil. However, negative effects of fat introduction in the diets of lactating cows on milk protein concentration are well documented in several reviews $(28,29)$. In another review, Doureau and Chilliard (30) reported that dairy cows experienced a reduction of milk protein concentration as consequence of an increase of dietary fat content after peak of lactation; they also reported that this reduction mainly interested casein content. Some experiments showed that the depressing effect of lipid administration were independent from the nature of lipids $(9,31,32)$. The causes of the impairing effect of diet fat on milk protein concentration are still unclear. The decrease of protein content seems to be explained by a reduction in casein content, that is synthetized in the mammary gland (30). In the cases where there was an increase of milk production (15), the negative effect on protein concentration might be due to the dilution of protein in a greater volume of milk. However, depressing effect seems to be more general and can be observed also when the production was not modified (13). Several other explanations were advanced: i. glucose deficiency; ii. insulin resistance; iii. increased energy efficiency in milk production; iv. somatotropin shortage (33). Any case, according to Sutton (34), the causes should be extra-ruminal, because the reduction of milk protein concentration was found with rumen-protected as well as unprotected lipids.

Main effect of SFC supplementation on milk fat concentration was not significantly different in respect to SBM diet (Tab. V). However, a significant interaction between lactation stage and dietary treatment was observed, if considering the effect separately in mid and late lactation (Fig. 1). In mid lactation, there was no difference in milk fat concentration between cows fed SBM and SFC; whereas, SFC supplementation determined a significant reduction of milk fat

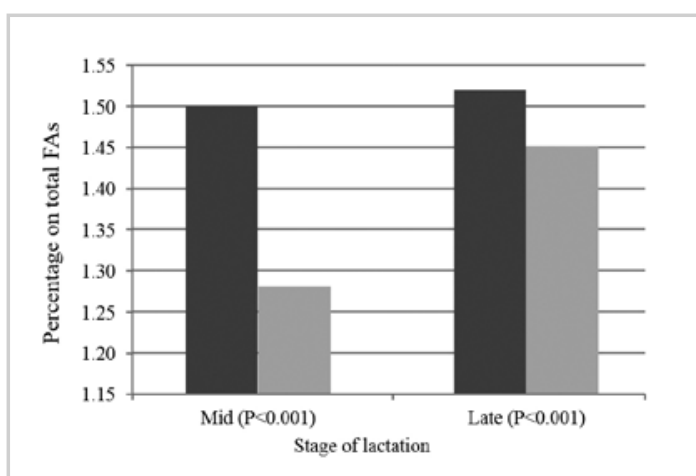

Figure 2. Percentage of UFAs C10:1 to C14:1 of milk fat of cows fed SBM (black bars) or SFC (gray bars) diet in mid or late stage of lactation. Figura 2. Percentuale di UFAs, dal C10:1 al C14:1, nel grasso di latte di bovine alimentate con SBM (barre in nero) o SFC (barre in grigio) nel medio e avanzato stadio di lattazione.

concentration in late lactation. There is a wide variability among the experiments where the effects of the supplementation of sunflower seed or oil on milk fat concentration were assessed. Some authors $(10,11)$ found a reduction of milk fat percentage as consequence of the supplementation of sunflower seeds or oil; on the contrary, in other studies no effects were found (12-15). The discrepancies among these experiments can be explained by differences in kind

\section{Table V. Milk production and milk fat and protein concentration of cows fed on control (SBM) and experimental (SFC) diets}

Tabella 5. Produzione di latte e concentrazione di grasso e proteine del latte di bovine alimentate con la dieta controllo (SBM) e sperimentale (SFC).

\begin{tabular}{|c|c|c|c|c|}
\hline & & \multicolumn{2}{|c|}{ Diet } & \multirow[b]{3}{*}{ SE } \\
\hline & & SBM & SFC & \\
\hline & & \multicolumn{2}{|c|}{ Mean } & \\
\hline Milk production & $(\mathrm{kg} / \mathrm{d})$ & 36.5 & 37.3 & 0.37 \\
\hline Fat concentration§ & (g/100g) & 4.03 & 3.82 & 0.01 \\
\hline Protein concentration ${ }^{\star *}$ & (g/100g) & 3.52 & 3.42 & 0.01 \\
\hline
\end{tabular}

**Significant main effect $(p<0.001)$; $\S$ significant interaction between treatment and stage of lactation $(p<0.05)$ 


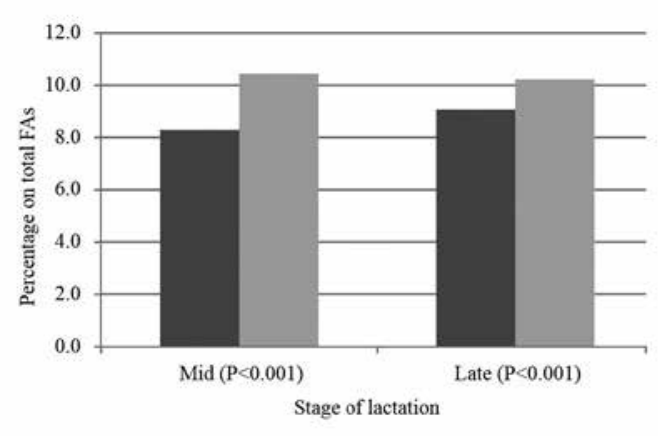

Figure 3. Percentage of $\mathrm{C} 18$ of milk fat of cows fed SBM (black bars) or SFC (gray bars) diet in mid or late stage of lactation.

Figura 3. Percentuale di C18 nel grasso di latte di bovine alimentate con SBM (barre in nero) o SFC (barre in grigio) nel medio e avanzato stadio di lattazione.

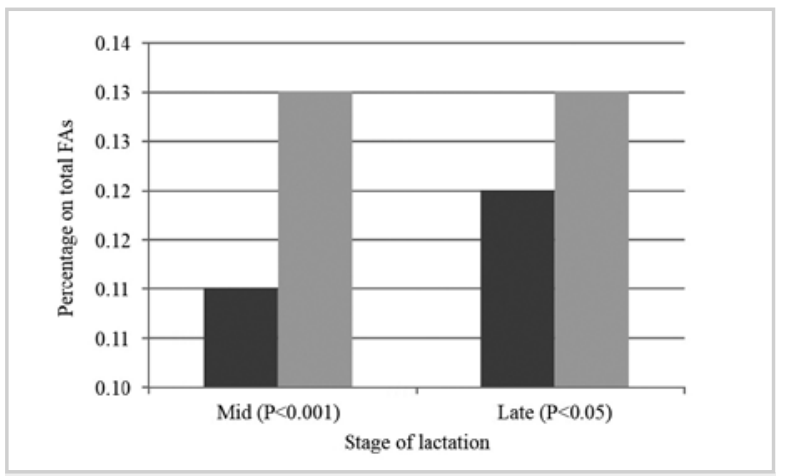

Figure 4. Percentage of the sum $\mathrm{C} 20$ to $\mathrm{C} 22$ of milk fat of cows fed SBM (black bars) or SFC (gray bars) diet in mid or late stage of lactation.

Figura 4. Somma delle percentuali dal C20 al C22 nel grasso di latte di bovine alimentate con SBM (barre in nero) o SFC (barre in grigio) nel medio e avanzato stadio di lattazione. of lipids fed to cows or lactation stage: Casper et al. (11) pointed out that milk fat concentration was depressed by regular sunflower seeds (rich in linoleic acid), whereas administration of high-oleic sunflower seeds did not have this effect. He et al. (35) confirmed this observation by finding that administration of high LA sunflower oil had a stronger effect than low LA sunflower compared with a nofat diet on milk fat production and percentage. For what concerns distance from calving, in the two experiments where cows in early lactation were used, milk fat concentration was not influenced by feeding treatment $(13,14)$.

Partial substitution of SBM with SFC significantly modified lipid composition of milk fat (Tab.VI), with an increase of UFA and a decrease of SFA. De novo synthetized FAs (C4 to C14) were not influenced by feeding treatment. Palmitic acid, which derives from de novo synthesis, but also from body fat mobilization and directly from feed, was decreased by SFC supplementation; on the contrary, percentage of stearic acid, that is not synthetized in mammary gland, was increased. Regarding this FA, we also observed a significant interaction between dietary treatment and lactation stage, with a higher difference between dietary treatment in mid than in late lactation (Fig. 3). Similar results have recently been obtained by Goiri et al. (36) who substituted hydrogenated palm fat with SFC and observed a significant decrease of $\mathrm{C} 12$ and $\mathrm{C} 16$ together with an increase of C18, C18:1 cis12, C18:1 trans10, C18:2 and C18:2 cis9, trans11.

Consistently to Glasser et al. (9) in the milk fat of the cows fed SBM there was a lower percentage of minor FAs than in that of cows receiving SFC. However, the differences of UFAs C10:1 to C14:1 (Fig. 2) and sum C20 to C22 (Fig. 4), between the two treatments, were higher in mid than in late lactation.

Oleic acid concentration was higher in the milk fat of cows fed SFC than in that of SBM cows (Tab.VI). Main source of C18:1 is desaturation of $\mathrm{C} 18$ through activity of $\Delta^{9}$ desaturase in the mammary gland (19). This finding could explain also the results obtained by $\mathrm{He}$ et al. (35), who reported increases of C18:1 with both high-oleic low-linoleic sunflower oil and low-oleic high-linoleic oil supplementation. Sunflower cake supplementation determined also increase of VA, CLA, LA and the sum C20 to C22. Lack of effects on $\omega-3$ was expected, since sunflower oil has a little percentage of $\alpha$-linolenic acid (19).

The diet fed to the cows of this experiment was rich in rapidly fermentable carbohydrates, that are present in maize silage and cereal grains. Even if the supply of roughages can be considered adequate, the increase of UFA in the diet makes the condition favorable for the reduction of milk fat percentage in late lactation. There are several reviews which discussed the milk fat depression syndrome; in one of them, Bauman and Griinari (37) explained that a high-grain with a low-roughage diet is a requisite for altering rumen microbial processes; but it does not determine any reduction of milk fat concentration, unless there is a sufficient amount of PUFA in the diet. Polyunsaturated fatty acids, such as C18:2, are toxic for microbial bacteria, which have to rapidly biohydrogenate them to SFA. Accor- 
ding with the "biohydrogenation theory", exposed by Perfield and Bauman (38), some intermediates, having an impairing effect on de novo FA synthesis in mammary gland, are formed. The intermediate that seems to have the greatest effect on milk fat synthesis is trans-10, cis 12 18:2, an increase of which is invariably associated with a reduction of milk fat concentration. In the experiment of Anguelo et al. (39), the administration of unprotected PUFA to lactating cows determined a reduction of milk secretion, which was associated with a down-regulation of mammary enzyme expression (steaoryl-CoA desaturase, SCD1; FA synthetase, FASN) and expression of the regulatory element binding transcription factor (SREBF-1). In a recent work, Wang et al. (40) demonstrated that also levels of CLA have direct effects on protein expression in isolated milk epithelial cells of mammary gland.

The modification of milk fat composition, induced by SFC substitution for a portion of SBM, gives some positive nutritional characteristics to the milk produced by cows on SFC diet. A higher content of PUFA corresponds to reduced contents of lauric, myristic and palmitic acids, that are considered the major responsible of the hypercholesterolemic effects of milk fat in comparison to vegetable oils (28). Furthermore, milk fat produced from cows fed SFC had higher levels of CLA, the most abundant conjugated octadecanoic FA in milk. In recent years, conjugated LA family received an extraordinary attention from the scientific community, because of the wide spectrum of its physiological effects (41), that make use of sunflower seeds and by-product very interesting in dairy cattle nutrition for obtaining an up-graded milk.

The abundance of CLA in milk is strongly dependent on the presence of LA in the diet, as said above, so that feeding SFC seems to be a very effective strategy to increase its content in milk.

\section{CONCLUSIONI}

This experiment evidenced that a partial substitution of SMB with SFC in the diet of lactating cows can be considered a feasible strategy for an economic exploitation of this co-product of biodiesel production chain.

Sunflower cake did not influence milk production, milk fat percentage and fat globule size on whole lactation. The reduction in milk fat percentage, observed in late lactation, is to be attributed to the impairing effect of $L A$ on the de novo FA synthesis in mammary gland. We obser-

\section{Table VI. Fatty acid composition (\% on total FA) of milk of cows fed on SBM or SFC diets}

Tabella VI. Composizione in acidi grassi (\% sul totale di FA) del latte di bovine alimentate con SBM e SFC.

\begin{tabular}{|c|c|c|c|}
\hline \multirow{3}{*}{ Fatty acid } & \multicolumn{2}{|c|}{ Diets } & \multirow[b]{3}{*}{ SE } \\
\hline & SBM & SFC & \\
\hline & \multicolumn{2}{|c|}{ Mean } & \\
\hline$\sum$ SFA C4 to $\mathrm{C} 14$ & 26.4 & 26.1 & 0.28 \\
\hline$\Sigma$ UFA C10 to $\mathrm{C} 14: 1^{* *} \S$ & 1.15 & 1.36 & 0.01 \\
\hline $\mathrm{C} 16^{\star \star}$ & 31.5 & 28.2 & 0.20 \\
\hline C16:1cis 7 e C16:1cis $9^{* *}$ & 1.70 & 1.39 & 0.23 \\
\hline C17:1 & 0.15 & 0.19 & 0.02 \\
\hline $\mathrm{C} 18^{\star \star} \S$ & 8.66 & 10.31 & 0.12 \\
\hline C18:1** & 21.3 & 22.9 & 0.24 \\
\hline C18:1trans11 (VA) ** & 0.87 & 1.21 & 0.04 \\
\hline C18:2cis9,trans11 (CLA) ${ }^{\star \star}$ & 0.47 & 0.63 & 0.02 \\
\hline C18:2cis9,cis12 (LA)** & 2.59 & 2.95 & 0.04 \\
\hline$\sum \mathrm{C} 20$ to $\mathrm{C} 22^{* *} \S$ & 0.11 & 0.13 & 0.002 \\
\hline $\mathrm{C} 20: 4 \mathrm{n} 6$ & 0.13 & 0.13 & 0.002 \\
\hline Others & 3.28 & 3.16 & 0.05 \\
\hline Total SFA ${ }^{\star *}$ & 70.0 & 67.9 & 0.31 \\
\hline Total UFA ${ }^{\star \star}$ & 30.0 & 32.1 & 0.31 \\
\hline Total MUFA ${ }^{\star \star}$ & 25.61 & 27.2 & 0.27 \\
\hline Total PUFA ${ }^{* *}$ & 4.39 & 4.90 & 0.50 \\
\hline Total $\omega-3$ acids & 0.39 & 0.38 & 0.05 \\
\hline
\end{tabular}

${ }^{\star *}$ Significant main effect $(p<0.001)$; $\S$ significant interaction between treatment and stage of lactation $(p<0.05)$

ved a reduction of milk protein concentration, according to several other experiments where vegetable oils were fed to lactating cows. The decrease of SFA and the increase of CLA, lent some positive nutritional characteristics to milk, and make this feeding strategy very interesting.

From this perspective, introduction of SFC in dairy cow diet is not only a strategy for an economic use of this by-product, but it is also a mean for improving milk nutritional properties.

\section{CONFLICT OF INTEREST}

The authors declare no competing financial interest.
ACKNOWLEDGMENT

This research was supported by the Italian Ministry of Agriculture, Food, Forestry Policies (MiPAAF), project "Valorizzazione dei sottoprodotti della filiera del biodiesel - EXTRAVALORE". 


\section{REFERENCES}

1. Chum H., Faaij A., Moreira J., Berndes G., Dhamija P., Dong H., Gabrielle B. et al. Bioenergy. In: IPCC special report on renewable energy sources and climate change mitigation. (eds. O. Edenhofer, R., Pichs-Madruga Y., Sokona K., Seyboth P., Matschoss S., T. Kadner Zwickel et al.), Cambridge University Press, Cambridge, United Kingdom and New York, NY, USA, 2011; 202-331.

2. Cooper, G., Weber, J.A. An outlook on world biofuel production and its implications for animal feed industries. In: Biofuel co-products as livestock feed. Opportunities and challenges, (ed. H.P.S. Makkar), Food and Agriculture Organization of the United Nations, FAO, Rome, 2012;1-12.

3. Zanetti F.F., Monti A., Bert, M.T. Challenges and opportunities for new industrial oilseed crops in EU-27: A review. Ind. Crops Prod. 2013; 50: 580-595.

4. Food and Agriculture Organization (FAO) www.fao.org/faostat. Accessed 21/1/2020 5. Calamai, A., Vai, T. La filiera dell'olio vegetale puro (OVP) per la produzione $\mathrm{d}$ energia. www.campuslab.eu/pubblicazioni. Accessed 21/1/2020.

6. ISTAT - Istituto Nazionale di Statistica - Caratteristiche tipologiche delle aziende agricole $6^{\circ}$ Censimento Generale dell'Agricoltura 2013.

7. Doppenberg J., van der Aar P.J. Applications of rapeseed meal or-expeller and glycerine in diets for non ruminants. In: Biofuels: implications for the feed industry, (eds. J. Doppenberg, P.J. van der Aar), Wageningen Academic Publishers, Wageningen, NL, 2007; 73-87.

8. Rabiee A.R., Breinhild K., Scott W., Golder H.M., Block E., Lean I.J. Effect of fat additions to diets of dairy cattle on milk production and components: A metaanalysis and meta regression. J. Dairy Sci. 2012; 95: 3225-3247.

9. Glasser F., Ferlay A., Chilliard Y. Oilseed lipid supplements and fatty acid composition of cow milk: A meta-analysis. J. Dairy Sci. 2008; 91: 4687-4703.

10. Sarrazin P., Mustafa A.F., Chouinard P.Y., Raghavan G.S.V., Sotocinal S.A. Performance of dairy cows fed roasted sunflower seeds. J. Sci. Food Agric. 2004; 84: $1179-1185$

11. Casper D.P., Schingoethe D.J., Middaugh R.P., Baer R.J. Lactational responses of dairy cows to diets containing regular and high oleic acid sunflower seeds. J. Dairy Sci. 1988; 71: 1267-1274

12. McGuffey R.K., Schingoethe D.J. Whole sunflower seeds for high producing dairy cows. J. Dairy Sci. 1982; 65: 1479-1483.

13. Petit H.V., Germiquet C., Lebel, D. Effect of feeding whole, unprocessed sunflower seeds and flaxseed on milk production, milk composition, and prostaglandin secretion in dairy cows. J. Dairy Sci. 2004; 87: 3889-3898.

14. Rafalowski W., Park, C.S. Whole sunflower seed as supplement for lactating cows. J. Dairy Sci. 1982; 65: 1482-1492.

15. Stegeman G.A., Casper D.P., Schingoethe D.J., Baer R.J. Lactational responses of dairy cows fed unsaturated dietary fat and receiving bovine somatotropin J. Dairy Sci. 1992; 75: 1936-1945.

16. Cruz-Hernandez C., Kramer J.K.G., Kennely J.J., Glimm D.R., Sorensen B.M. Okine E.K.et al. Evaluating the conjugated linoleic acid and trans 18:1 isomers in milk fat in dairy cows fed increasing amounts of sunflower oil and constant level of fish oil. J. Dairy Sci. 2007; 90: 3786-3801.

17. Rego O.A., Alves S.P., Antunes L.M.S., Rosa H.J.D., Alfaia C.F.M., Prates J.A.M. et al. Rumen biohydrogenation-derived fatty acids in milk fat from grazing cows supplemented with rapeseed, sunflower, or linseed oils. J. Dairy Sci. 2009; 92: $4530-4540$

18. McCrorie T.A., Keaveney E.M., Wallace J.M., Binns N., Livingstone M.B. Human health effects of conjugated linoleic acid from milk and supplements. Nutr. Res. Rev. 2011; 24: 206-227.

19. Collomb M., Schmid A., Sieber R., Wechsler D., Ryhänen E.-L. Conjugated linoleic acids in milk fat: Variation and physiological effects. Int. Dairy J. 2006; 16 1347-1361.

20. Südekum K.-H. By-products from biodiesel production: glycerine and rapeseed products in rations for farm animals. In: Biofuels: implications for the feed industry(eds. J. Doppenberg, J. van der Aar) Wageningen Academic Publishers; Wageningen, NL, 2007: 61-72.
21. AOAC. Official methods of analysis of AOAC international (29th Ed.) Animal Feed Chapter 4, G. Latimer (Editor) AOAC International, Rockville, MD, USA. 2016

22. Contarini G., Povolo, M., Pelizzola, V., Monti, L., Bruni, A., Passolungo, L., Abeni, F., Degano, L. Bovine colostrum: Changes in lipid constituents in the first 5 days after parturition. J. Dairy Sci. 2014; 97: 5065-5072.

23. ISO (International Organization for Standardization). Standard 14156. Milk and milk products. In: Extraction methods for lipids and liposoluble compounds. ISO, Geneva, Switzerland; 2001.

24. ISO (International Organization for Standardization). Standard 15884. Milk fat. In: Preparation of fatty acid methyl esters. ISO, Geneva, Switzerland; 2002.

25. Cabassi G., Profaizer M., Marinoni L., Cattaneo T.M.P. Estimation of milk fat globule distribution in milk using scattering in the near infrared region. In: Proc. 15th Inter. Conf., Near Infrared Spectrometry. (eds Manley M., Mc Goverin C.M., Thomas D.B., Downey G.) Cape Town, South Africa 2012: 214-218.

26. ISO (International Organization for Standardization). Standard 13320. Particle size analysis - Laser diffraction methods. ISO, Geneva, Switzerland; 2009.

27. Chilliard Y. Dietary fat and adipose tissue metabolism in ruminants, pigs, and rodents: A review. J. Dairy Sci. 1993; 76: 3897-3931.

28. Palmquist D.L., Jenkins T.C. A 100-Year Review: Fat feeding of dairy cows. J. Dairy Sci. 2017; 100: 10061-10077

29. Jenkins T.C., McGuire M.A. Major advances in nutrition: Impact on milk composition. J. Dairy Sci. 2006; 89: 1302-1310.

30. Doreau M., Chilliard, Y. Digestion and metabolism of dietary fat in farm animals. Br. J. Nutr. 1997; 78: S15-S35.

31. Lock A.L., Garnsworthy P.C. Independent effects of dietary linoleic and linolenic fatty acids on the conjugated linoleic acid content on cows' milk. Anim. Sci. 2002; 74: 163-176.

32. Murphy J.J., Coakley M., Stanton C. Supplementation of dairy cows with a fish oil containing supplement and sunflower oil to increase the CLA content of milk produced at pasture. Livest. Sci. 2008; 116: 332, 337.

33. Wu Z., Huber J.T. Relationship between dietary fat supplementation and milk protein concentration in lactating cows: A review. Livest. Prod. Sci. 1994; 39: 141 155.

34. Sutton J.D. Altering milk composition by feeding. J. Dairy Sci. 1989;72: 2801 2814.

35. He M., Perfield K.L., Green H.B., Armentano L.E. Effect of dietary fat blend enriched in oleic or linoleic acid and monensin supplementation on dairy cattle performance, milk fatty acid profiles, and milk fat depression. J. Dairy Sci. 2012; 95: 1447-1461.

36. Goiri I., Zubiria I., Benhissi H., Atxaerandio R., Ruiz, R., Mandaluniz N., et al. Use of cold-pressed sunflower cake in the concentrate as a low-input local strategy to modify the milk fatty acid profile of dairy cows. Animals 2019; 9: 803-817. 37. Bauman D.E., Griinari J.M. Regulation and nutritional manipulation of milk fat: low-fat milk syndrome. Livest. Prod. Sci. 2001; 70: 15-29.

38. Perfield J.W., Bauman D.E. Current theories and recent advances in the biology of milk fat depression. In: Proc. Cornell. Nut.Conf. Feed Manuf. Ithaca, 2005; 95-106

39. Anguelo J., Mahecha L., Nuernberg K., Nuernberg G., Dannenberg D., Olivera M. et al. Effects of polyunsaturated fatty acids from plant oils and algae on milk fat yield and composition are associated with mammary lipogenic and SREBF1 gene expression. Animal, 2012; 6:1961-1972.

40. Wang T., Lim J.-N., Bok J.-D., Kim J.-H., Kang S.K., Lee, S.B. et al. Association of protein expression in isolated milk epithelial cells and cis-9, trans-11 conjugated linoleic acid proportions in milk from dairy cows. J. Sci. Food Agric. 2014 94:1835-43.

41. Hellgren L.I., Nordby, P. Bioactive Lipids in Dairy Fat. In: Dairy in Human Health and Disease Across the Lifespan, Chapter 17 (Eds: R. R. Watson, R. J. Collier, V. R. Preedy) Academic Press, 2017; 233-237. 


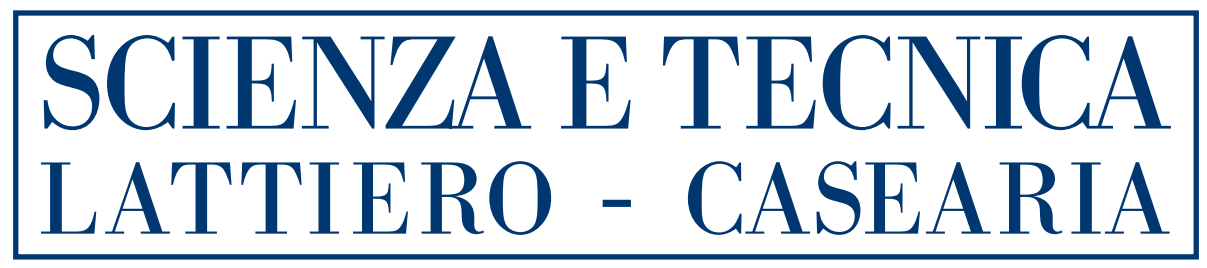

Italian Journal of Dairy Science and Technology

\section{New online submission and review system}

Scienza e tecnica lattiero casearia uses an online submission and review system for all papers evaluation.

Electronic submission allows a more efficient processing of manuscripts and offers Authors the option to track the progress of the review process whenever they need to.

The link to the editorial system is http://stlcj.edmgr.com, it is also available on the Journal website:

www.stlcjournal.it.

The Authors are invited to submit their manuscripts through the online editorial system; manuscripts sent by e-mail, post or fax are not considered for publication.

All the Authors should read carefully the Guide for Authors before starting their submissions. Full information about the manuscript preparation are available on the Journal website.

During submission, Authors will be first asked to select the article type, enter the manuscript title and provide Author information. Through a menu, a general topic area should be selected: these will help to match manuscripts to the best available editors and reviewers.

Reviewers will access papers via the editorial system platform and will be invited and sent to it by email.

Full Authors Guidelines, online Submission System link, Journal Publishing Agreement and Conflict of interest forms are available on the Journal website:

www.st/cjournal.it

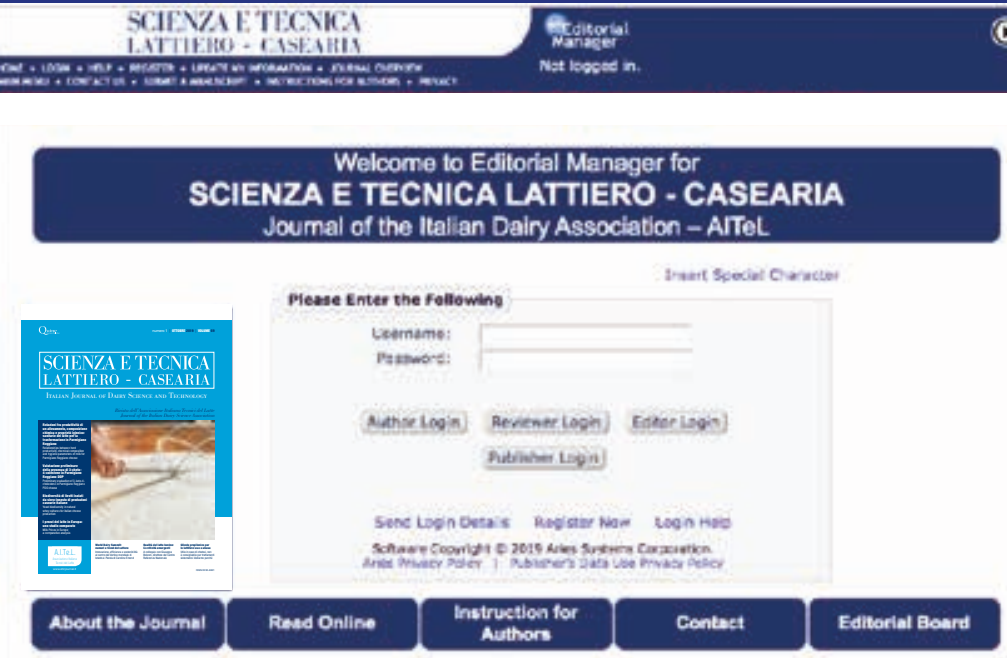

First-time users: Pleass dick on the werd 'Register' in the navigution tar at the tee of the page and encer the requested inlormation. Upon successful teg stration, you wil be sent an e-mal with instructions to verify your registration. NOTE. If you received an e-mal tram us whth an assigned user ID and pastword, DO NOT REGLSTER ACAN. Simply use that informason to login. Usememes end passwores may se changed atber registration isec instructions beiow).

Repeat users: Plosse dick the Zogin' button tram the menu above and proceed as approprate.

Authors. Please click the "Login" butch fom the rnenv above and login to the sysiem as "Author"." You may then sukmit your manucript and track is progress through the syslem

Reviewers: Please clide the "Login" bution frem the menu above and logh to the system as "Reviever." You may then vew andice download manuscrios assigned to you for review or submit your conmerts to the editor and the authors.

To ehange your username andior password: Once you ace regitered, yeu may change yout contact informasion. usemame andio password at any bee. Simply log in to the systom and click on "Update My Information" in the nurvigation bar at the top of the page. 